DEPARTMENT OF THE INTERIOR UNITED STATES GEOLOGICAL SURVEY

PREPARED IN COOPERATION WITH THE DIVISION OF BIOLOGY AND MEDICINE U.S. ATOMIC ENERGY COMMISSION

\title{
NATURAL GAMMA AERORADIOACTIVITY OF THE OAK RIDGE NATIONAL LABORATORY AREA, TENNESSEE AND KENTUCKY
} By

Robert G. Bates

GEOPHYSICAL INVESTIGATIONS

MAP GP-308

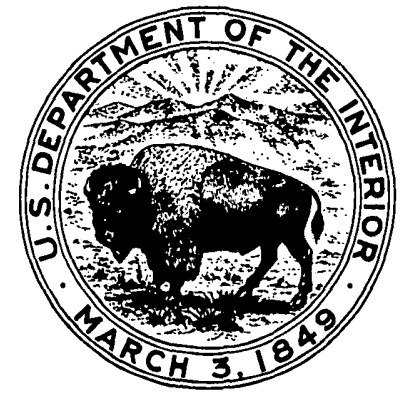

